\title{
Gamma Radiation Treatment for Reducing Cytotoxicity and Mutagenicity in Industrial Wastewater
}

\author{
Munawar Iqbal ${ }^{1 *}$, Mazhar Abbas², Muhammad Arshad², Tariq Hussain ${ }^{3}$, \\ Aman Ullah Khan ${ }^{4}$, Nasir Masood ${ }^{5}$, Muhammad Asif Tahir ${ }^{6}$, Syed Makhdoom Hussain ${ }^{7}$, \\ Tanveer Hussain Bokhari, Rasheed Ahmad Khera ${ }^{6}$ \\ 'National Centre of Excellence in Physical Chemistry, University of Peshawar, Peshawar-25120, Pakistan \\ ${ }^{2}$ Department of Basic Sciences, Biochemistry Section, College of Veterinary and Animal Sciences, \\ Jhang Campus-35200, Pakistan \\ ${ }^{3}$ Department of Basic Sciences, Pharmacology Section, College of Veterinary and Animal Sciences, \\ Jhang Campus-35200, Pakistan \\ ${ }^{4}$ Department of Pathobiology/Microbiology, College of Veterinary and Animal Sciences, Jhang Campus-35200, Pakistan \\ ${ }^{5}$ Department of Environmental Sciences, COMSATS Institute of Information Technology, Vehari-61100, Pakistan \\ ${ }^{6}$ Department of Chemistry, University of Agriculture, Faisalabad-38040, Pakistan \\ ${ }^{7}$ Department of Zoology, Government College University, Faisalabad, Pakistan \\ ${ }^{8}$ Department of Chemistry, Government College University, Faisalabad-38000, Pakistan
}

Received: May 26, 2015

Accepted: August 27, 2015

\begin{abstract}
Our study evaluates the effect of gamma radiation treatment on detoxification of textile effluents. The effluents were tested for cytotoxicity and mutagenicity using Allium cepa, heamolytic, brine shrimp, and Ames tests before and after gamma radiation treatment. The collected wastewater samples were irradiated to the absorbed doses of $5 \mathrm{kGy}, 10 \mathrm{kGy}$, and $15 \mathrm{kGy}$, and subjected to toxicity tests. The gamma radiation showed promising efficiency for detoxification of pollutants in wastewater. The microbial load was reduced to zero, and increases in root length (RL) and root count (RC) were $31.10 \%$ and $38.34 \%$, respectively, at $5 \mathrm{kGy}$. The reduction in cytotoxicity was recorded to be $39.56 \%, 49.65 \%$, and $79.63 \%$ in the case of human and sheep red blood cells (RBC) and brine shrimp, respectively. Before treatment, the samples were mildly mutagenic and after treatment mutagenicity was not detected. Results showed that gamma radiation has promising efficiency for the degradation of toxic agents present in effluents.
\end{abstract}

Keywords: absorbed dose, cytotoxicity, mutagenicity, wastewater, bioassays

\section{Introduction}

Advanced oxidation processes (AOP) are employed for wastewater treatment, especially for the degradation of organic compounds and mineralization. During AOP treat-

*e-mail: bosalvee@yahoo.com ment a strong oxidizing species (i.e., ${ }^{\circ} \mathrm{OH}$ radical) is produced in situ, which breaks down the complex organic molecule into harmless substances such as $\mathrm{CO}_{2}, \mathrm{H}_{2} \mathrm{O}$, and inorganic ions through chain reactions [1-5]. Although AOPs have been employed successfully for the degradation of organic molecules (i.e., dyes, pesticides, antibiotics and other recalcitrant compounds), toxicity is still a mystery 
and the development of an efficient, cost-effective, and green technique that can degrade and detoxify the toxic substances instead of transforming them into other phases is required [4, 6-10]. These processes are easy to handle, produce less residual effects as compared to classical treatment approaches, and are being employed for color removal, and mineralization of toxic chemicals and industrial wastewater [2, 11-13]. Currently, the trend in the development of innovative technologies is focused on those processes that eventually cause destruction of the organic contaminants rather than transferring them into another form. The application of high-energy radiation has been determined to be efficient in this regard [3, 14, 15]. The radiation-induced degradation of wastewater by gamma radiation, electron beam, and UV radiation is drawing more attention around the world. The treatment of wastewater effluents by radiation has advantages such as degrading non-biodegradable organic systems, not causing secondary pollution, and being cost-effective and ecofriendly $[2,16]$.

In view of partial oxidation of organic contaminants [17-20], the monitoring of treated effluents by AOPs is necessary and bioassays are routinely used to evaluate toxicity of treated effluent $[21,22]$. Bioassays have been used to evaluate toxicity of raw and treated industrial effluents [2, 23, 24]. Allium cepa among higher plants is regarded as efficient for toxicity evaluation [24, 25], and today brine shrimp and heamolytic are also in use for cytotoxicity monitoring of raw and treated effluents [3]. The Ames test is a reference test in chemical mutagenicity testing and was extensively validated [26]. Previously, AOPs such as $\mathrm{TiO}_{2} / \mathrm{UV}, \mathrm{O}_{3}$, electro-Fenton, wet-air oxidation, UV/electro-Fenton, photo-Fenton, sunlight irradiation, $\mathrm{TiO}_{2}$-based photocatalysis, $\mathrm{H}_{2} \mathrm{O}_{2} / \mathrm{UV}, \mathrm{O}_{3} / \mathrm{UV}$, and $\mathrm{TiO}_{2} / \mathrm{H}_{2} \mathrm{O}_{2} / \mathrm{UV}$ [23] treatment efficiency have been evaluated using bioassays.

Therefore, it has been hypothesized that gamma radiation has the ability to detoxify textile effluents and that bioassays can be used to measure the extent of detoxification. The textile wastewater collected from different industries was treated by gamma radiation to absorbed doses of $5 \mathrm{kGy}, 10 \mathrm{kGy}$, and $15 \mathrm{kGy}$, and the treatment effect was evaluated on the basis of microbial load, cytotoxicity, and mutagenicity reduction.

\section{Material and Methods}

Wastewater was collected from three textile industries from Faisalabad, Pakistan. The sampling was performed precisely using standard sampling methods [3]. Briefly, the plastic gallon jugs were pre-cleaned by soaking in nitric acid $1 \%(\mathrm{v} / \mathrm{v})$ for $24 \mathrm{~h}$ and rinsed with distilled water. Samples in triplicate were collected from each industry. The collected samples were transported to the laboratory and kept at $4^{\circ} \mathrm{C}$. After preliminary evaluation, samples were irradiated to gamma radiation absorbed doses of 5, 10, and $15 \mathrm{kGy}$ using a Cesium-137 gamma radiation source at the Nuclear Institute for Agriculture and Biology (NIAB) in
Faisalabad, Pakistan. The dose rate at the time of sample irradiation was $1.25 \mathrm{kGy} \cdot \mathrm{h}^{-1}$ (March 2011). The gamma radiation source was calibrated with a Fricke dosimeter and the absorbed dose was calculated by relation shown in Eq. (1):

$$
D=\left[\frac{N_{A} \cdot \Delta A \cdot 100}{\epsilon \cdot \rho \cdot G(F e(I I I))}\right]
$$

...where $D$ is absorbed dose, $N_{A}$ is Avogadro's number $\left(6.02 \times 10^{23}\right), \Delta A$ represents absorbance difference of irradiated and un-irradiated samples, $\rho$ is the density of dosimetric solution $\left(1.024 \mathrm{~g} / \mathrm{cm}^{3}\right.$ for $\left.0.4 \mathrm{M} \mathrm{H}_{2} \mathrm{SO}_{4}\right), \epsilon$ is the molar extinction coefficient of ferric ion $\left(0.2205 \mathrm{M}^{-1} \cdot \mathrm{cm}^{-1}\right.$ at 304 and $\left.25^{\circ} \mathrm{C}\right)$, and $\mathrm{G}(\mathrm{Fe}(\mathrm{III}))$ is the number of $\mathrm{Fe}^{+3}$ ions produced/100ev of absorbed energy (15.6) for Fricke solution. The water quality parameters before irradiation were measured using standard methods. $\mathrm{pH}$, dissolved oxygen (DO), biological oxygen demand (BOD), and chemical oxygen demand (COD) were measured using pre-calibrated $\mathrm{pH}$, DO, BOD, and COD meters (Lovibond), whereas TDS and TSS were measured using the already reported method [27].

To evaluate the effect of gamma radiation on toxicity reduction, the toxicity of wastewater sample was measured before and after gamma radiation treatment. Bioassays such as Allium cepa, heamolytic, brine shrimp (cytotoxicity tests), and Ames tests (mutagenicity test) were performed [27]. The microbial load (total bacterial and total coliform) was also recorded before and after gamma radiation treatment. All samples were seeded in triplicate except Allium cepa test (five repetitions) and responses thus obtained were averaged and reported as mean \pm standard deviation. The Allium cepa, [24, 25], brine shrimp, and heamolytic tests are used for cytotoxicity evaluation [28], whereas Ames test is a standard test in chemical mutagenicity testing [26]. These tests were performed in the guideline of chemical testing using bioassays [29, 30].

\section{Results and Discussion}

The effect of gamma radiation treatment on microbial load, cytotoxicity and mutagenicity was investigated in the present study. The textile wastewater samples were irradiated to the gamma radiation absorbed doses of 5, 10, $15 \mathrm{kGy}$ and subjected to toxicity analysis and results, and thus obtained were compared with control (un-treated samples). Before treatment, the measured values of microbial load, cytotoxicity, and genotoxicity are shown in Table 1. The total bacterial count (TBC) and total coliform (TC) populations were recorded as $>1 \times 10^{6} \mathrm{CUF}$ and $>1 \times 10^{5}$ CUF, respectively.

Allium cepa, hemolytic, and brine shrimp tests showed that the textile wastewater was cytotoxic in nature. In comparison to positive control, $41.0 \%, 54.44 \%, 19.0 \%, 29.0 \%$, and $32.0 \%$ higher cytotoxicity was recorded through RC, RL, human, sheep, and shrimp tests, respectively, which revealed that cytotoxic agents are commonly present in tex- 
Table 1. Microbial load, cytotoxicity, and mutagenicity of textile wastewater before treatment.

\begin{tabular}{|c|c|c|c|c|c|c|c|}
\hline \multirow{2}{*}{ Bioassays } & \multirow{2}{*}{ Types } & \multirow{2}{*}{ Units } & \multicolumn{3}{|c|}{ Wastewater } & \multicolumn{2}{|c|}{ Control } \\
\hline & & & Industry I & Industry II & Industry III & Positive & Negative \\
\hline \multirow{2}{*}{ Microbial load } & TBC & $\mathrm{CFU}$ & $>1 \times 10^{6}$ & $>1 \times 10^{6}$ & $>1 \times 10^{6}$ & - & - \\
\hline & $\mathrm{TC}$ & $\mathrm{CFU}$ & $>1 \times 10^{5}$ & $>1 \times 10^{5}$ & $>1 \times 10^{5}$ & 0.000 & 0.000 \\
\hline \multirow{7}{*}{ Cytotoxicity } & \multicolumn{7}{|c|}{$\mathrm{ACT}$} \\
\hline & I) $\mathrm{RC}$ & counts & $10 \pm 0.15$ & $9 \pm 0.25$ & $11 \pm 0.20$ & $17 \pm 0.26$ & $08 \pm 0.20$ \\
\hline & II) RL & $\mathrm{cm}$ & $4.1 \pm 0.06$ & $3.9 \pm 0.04$ & $3.8 \pm 0.05$ & $9.0 \pm 0.15$ & $2.5 \pm 0.04$ \\
\hline & \multicolumn{7}{|c|}{ Heamolytic } \\
\hline & I) human & $\%$ & $81 \pm 1.6$ & $78 \pm 1.8$ & $72 \pm 1.9$ & $100 \pm 0.0$ & 0.000 \\
\hline & II) sheep & $\%$ & $71 \pm 0.9$ & $69 \pm 1.5$ & $75 \pm 1.3$ & $100 \pm 0.0$ & 0.000 \\
\hline & Shrimp & - & $68 \pm 0.80$ & $64 \pm 0.85$ & $54 \pm 0.81$ & $100 \pm 0.0$ & 0.000 \\
\hline \multirow{3}{*}{ Mutagenicity } & \multicolumn{7}{|c|}{ Ames test } \\
\hline & I) TA98 & counts & $62 \pm 2 / 96$ & $59 \pm 2 / 96$ & $60 \pm 1 / 96$ & $19 \pm 2 / 96$ & 0.000 \\
\hline & II) TA100 & counts & $68 \pm 2 / 96$ & $63 \pm 2 / 96$ & $61 \pm 3 / 96$ & $21 \pm 2 / 96$ & 0.000 \\
\hline
\end{tabular}

TBC - total bacterial count, TC - total coliform, ACT - Allium cepa test, RC - root count, RL - root length, "_," = not measured, $\mathrm{ND}$ - not detected, $\mathrm{PC}$ - positive control, $\mathrm{NC}$ - negative control.

For heamolytic test, $\mathrm{PC}$ and $\mathrm{NC}$ were TritonX-100 (0.1\%) and phosphate buffer saline, respectively.

For ACT, PC, and NC were distilled water and methyl methanesulfonate (MMS) (10 mg/L), respectively.

For shrimp test, $\mathrm{PC}$ and $\mathrm{NC}$ were cyclophosphamide $(10 \mu \mathrm{g} / \mathrm{mL})$ and sea water, respectively.

For Ames test, PC for TA98 and TA100 were $\mathrm{K}_{2} \mathrm{Cr}_{2} \mathrm{O}_{7}\left(0.01 \mathrm{~g} / \mathrm{L}\right.$ ) and $\mathrm{NaN}_{3}(0.5 \mu \mathrm{g} / 100 \mu \mathrm{l}$ ), respectively, and background (without standard and tested compound) was used as NC.

tile effluents. The Ames test also indicated the presence of mutagenic agents in textile wastewater. However, the mutagenic level was mild, detected through TA98 and TA100 (Table 1). Previous studies also showed that the textile wastewater has the potential to cause toxicity, which is attributed to a different variety and nature of dyes and other compounds present in wastewater [31-34].

The results of microbial load, cytotoxicity, and mutagenicity reduction of gamma radiation-treated samples to the absorbed doses of $5 \mathrm{kGy}, 10 \mathrm{kGy}$ and $15 \mathrm{kGy}$, evaluated through different bioassays are shown in Table 2. Microbial loads such as TBC and TC are reduced to zero, even at $5 \mathrm{kGy}$ absorbed dose irradiation. The TBC and TC counts before treatment were $>1 \times 10^{6}$ and $>1 \times 10^{5} \mathrm{CUF}$, respectively, which indicates that the gamma radiation treatment hampered the microbes and after treatment even a single microbe was not detected. Regarding cytotoxicity reduction, evaluated through Allium cepa, heamolytic (human and sheep RBC), and shrimp tests, promising responses are seen. The increase in RC and RL for wastewater irradiated at the absorbed dose $5 \mathrm{kGy}$ was $28.57 \%$ and $31.87 \%$, respectively, and by increasing the absorbed dose to $10 \mathrm{kGy}$ and $15 \mathrm{kGy}$, the RC and RL improvement was insignificant. The heamolytic and brine shrimp tests also showed a similar trend regarding toxicity reduction, at high doses the effect was insignificant as compared to low doses. The reduction in $\mathrm{RBC}$ cell death was $49.38 \%$ (human) and $46.47 \%$ (sheep) for the absorbed dose of $10 \mathrm{kGy}$, whereas it was $50.61 \%$ and $52.11 \%$ for the absorbed dose of $15 \mathrm{kGy}$, respectively, which indicates that by increasing the dose form $10 \mathrm{kGy}$ to $15 \mathrm{kGy}$, the effect regarding toxicity reduction was non-linear. In the case of brine shrimp test, the reduction in shrimp nauplii death was observed up to $77.77 \%, 77.77 \%$, and $88.88 \%$ for the absorbed doses of $5 \mathrm{kGy}, 10 \mathrm{kGy}$, and $15 \mathrm{kGy}$, respectively. On average basis, $31.10 \%, 38.34 \%, 39.56 \%, 49.65 \%$, and $79.63 \%$ toxicity reduction was recorded in the case of $\mathrm{RC}, \mathrm{RL}$, human, sheep, and shrimp tests, respectively, whereas $100 \%$ reduction in microbial load was achieved and cytotoxicity reduction was highly significant as compared to control for the absorbed $5 \mathrm{kGy}$, and at higher absorbed doses (10 kGy and $15 \mathrm{kGy}$ ) the effect was not significant as compared to $5 \mathrm{kGy}$. The preliminary test performed regarding water quality parameters also indicated that the water quality parameter values were beyond the permissible limits and might be responsible for toxicity of effluents because the nature of textile wastewater is complex due to presence of dyes, auxiliary compounds, and other salt additives.

The water assurance parameters (i.e., $\mathrm{pH}, \mathrm{COD}, \mathrm{BOD}$, TDS, and TSS) were recorded up to $11.8,2,100 \mathrm{mg} / \mathrm{L}$, $800 \mathrm{mg} / \mathrm{L}, 1,590 \mathrm{mg} / \mathrm{L}$, and $505 \mathrm{mg} / \mathrm{L}$, respectively, and dissolve oxygen (DO) was also recorded to be low. The insignificant effect of gamma radiation treatment at higher absorbed doses might be due to the high pollutant concentration in textile effluents and, secondly, there may be some compounds unable to degrade even at highabsorbed doses and the degradable agent are destructed at low dose. 
Table 2. Microbial load, cytotoxicity, and mutagenicity of textile wastewater after gamma radiation treatment to the absorbed doses of $5 \mathrm{kGy}, 10 \mathrm{kGy}$, and $15 \mathrm{kGy}$.

\begin{tabular}{|c|c|c|c|c|c|c|c|c|c|c|c|c|}
\hline \multirow{2}{*}{ Bioassays } & \multirow{2}{*}{ Types } & \multirow{2}{*}{ Units } & \multicolumn{3}{|c|}{ Industry I } & \multicolumn{3}{|c|}{ Industry II } & \multicolumn{3}{|c|}{ Industry III } & \multirow{2}{*}{ Average } \\
\hline & & & 5 kGy & 10 kGy & $15 \mathrm{kGy}$ & 5 kGy & $10 \mathrm{kGy}$ & 15 kGy & 5 kGy & $10 \mathrm{kGy}$ & $15 \mathrm{kGy}$ & \\
\hline \multirow{2}{*}{$\begin{array}{c}\text { Microbial } \\
\text { load }\end{array}$} & $\mathrm{TBC}$ & $\mathrm{CFU}$ & ND & ND & - & ND & ND & - & ND & - & - & - \\
\hline & $\mathrm{TC}$ & $\mathrm{CFU}$ & ND & ND & - & ND & ND & - & ND & ND & - & - \\
\hline \multirow{7}{*}{ Cytotoxicity } & \multicolumn{12}{|c|}{$\mathrm{ACT}$} \\
\hline & I) $\mathrm{RC}$ & count & $14 \pm 0.25$ & $14 \pm 0.3$ & - & $15 \pm 0.54$ & $16 \pm 0.3$ & $16 \pm 0.5$ & $14 \pm 0.43$ & $15 \pm 0.5$ & $15 \pm 0.3$ & - \\
\hline & I) $\mathrm{RL}$ & $\mathrm{cm}$ & $6.2 \pm 0.15$ & $6.0 \pm 0.2$ & $6.4 \pm 0.2$ & $5.8 \pm 0.30$ & $6.8 \pm 0.5$ & - & $6.6 \pm 0.60$ & $7.0 \pm 0.5$ & $6.9 \pm 0.6$ & - \\
\hline & \multicolumn{12}{|c|}{ Heamolytic } \\
\hline & I) human & $\%$ & - & $41 \pm 1.0$ & $40 \pm 1.3$ & $53 \pm 2.10$ & $45 \pm 1.1$ & $44 \pm 1.3$ & $51 \pm 1.99$ & $50 \pm 2.8$ & $44 \pm 1.5$ & - \\
\hline & II) sheep & $\%$ & $38 \pm 2.00$ & $37 \pm 2.1$ & $34 \pm 1.9$ & $41 \pm 2.50$ & $39 \pm 2.9$ & $33 \pm 1.7$ & $37 \pm 1.10$ & - & $26 \pm 2.0$ & - \\
\hline & Shrimp & - & $4 \pm 1.00$ & $4 \pm 1.00$ & $2 \pm 1.00$ & $5 \pm 1.00$ & $4 \pm 2.10$ & - & $6 \pm 1.00$ & $4 \pm 2.0$ & $2 \pm 1.0$ & - \\
\hline \multirow{3}{*}{ Mutagenicity } & \multicolumn{12}{|c|}{ Ames test } \\
\hline & I) TA98 & count & $33 \pm 2.00$ & $29 \pm 1.0$ & - & $35 \pm 1.50$ & $33 \pm 1.0$ & $33 \pm 1.0$ & $30 \pm 3.00$ & $31 \pm 2.0$ & $28 \pm 2.0$ & - \\
\hline & II) TA100 & count & $41 \pm 1.00$ & $38 \pm 1.0$ & $36 \pm 1.0$ & $39 \pm 2.00$ & - & $34 \pm 2.0$ & $35 \pm 1.50$ & $33 \pm 1.0$ & $29 \pm 1.0$ & - \\
\hline \multicolumn{13}{|c|}{ Percentage toxicity reduction after treatment } \\
\hline \multirow{2}{*}{$\begin{array}{c}\text { Microbial } \\
\text { load }\end{array}$} & $\mathrm{TBC}$ & $\%$ & 100 & 100 & 100 & 100 & 100 & 100 & 100 & 100 & 100 & 100 \\
\hline & $\mathrm{TC}$ & $\%$ & 100 & 100 & 100 & 100 & 100 & 100 & 100 & 100 & 100 & 100 \\
\hline \multirow{7}{*}{ Cytotoxicity } & \multicolumn{12}{|c|}{ ACT } \\
\hline & I) $\mathrm{RC}$ & $\%$ & 28.57 & 28.57 & - & 40 & 43.75 & 43.75 & 28.57 & 33.33 & 33.33 & 31.10 \\
\hline & I) $\mathrm{RL}$ & $\%$ & 31.78 & 32.66 & 33.87 & 32.75 & 42.64 & - & 42.42 & 45.71 & 44.92 & 38.34 \\
\hline & \multicolumn{12}{|c|}{ Heamolytic } \\
\hline & I) human & $\%$ & - & 49.38 & 50.61 & 32.05 & 42.3 & 43.58 & 29.16 & 30.55 & 38.88 & 39.56 \\
\hline & II) sheep & $\%$ & 46.47 & 46.47 & 52.11 & 40.57 & 43.47 & 52.17 & 50.6 & - & 65.33 & 49.65 \\
\hline & Shrimp & - & 77.77 & 77.77 & 88.88 & 73.68 & 78.94 & - & 70 & 80 & 90 & 79.63 \\
\hline \multirow{3}{*}{ Mutagenicity } & \multicolumn{12}{|c|}{ Ames test } \\
\hline & I) TA98 & $\%$ & 46.77 & 53.22 & - & 40.67 & 44 & 44 & 50 & 48.33 & 53.33 & 47.54 \\
\hline & II) TA100 & $\%$ & 39.7 & 44.11 & 47 & 38 & - & 46 & 42.62 & 49.18 & 54.09 & 45.09 \\
\hline
\end{tabular}

"_" - not measured, ND - not detected, ACT - Allium cepa test, RC - root count, RL - root length

The representative textile wastewater samples were also tested for mutagenicity before and after gamma radiation treatment and results (Table 2; Ames test). The untreated wastewater sample showed mild mutagenicity and, after gamma radiation treatment, the mutagenicity was reduced significantly and up to $46.77 \%$ and $39.7 \%$ reduction was observed in the case of TA98 and TA100, respectively, for the gamma radiation absorbed dose of $5 \mathrm{kGy}$. A reduction in mutagenicity was $53.22 \%$ in the case of TA98 for the absorbed dose of $10 \mathrm{kGy}$, whereas in the case of TA100 it was $44.11 \%$ and $47.00 \%$ for the absorbed doses of $10 \mathrm{kGy}$ and $15 \mathrm{kGy}$, respectively, for effluents from industry I, and a similar trend was observed for industry II and III. Overall, reduction in mutagenicity was recorded to be $47.54 \%$ and
$45.09 \%$, respectively, for TA98 and TA100. From the results of the Ames test, it can be concluded that gamma radiation treatment has the ability to degrade a mutagenic agent present in industrial wastewater.

In recent years, different AOPs have been investigated for the removal of emerging contaminants from wastewater and drinking water, etc., and it also has been observed that the AOP are able to detoxify the toxic agent [2, 27]. The detoxification behavior might be due the degradation of toxic compounds into harmless by-product as a result of the action of the hydroxyl radical [3-5]. Few studies have reported the toxicity of treated samples by AOP; however, the studies regarding gamma radiation effect on toxicity are rare. Therefore, textile wastewater was subject to gamma 
radiation treatment to the absorbed doses of $5 \mathrm{kGy}, 10 \mathrm{kGy}$, and $15 \mathrm{kGy}$, and treatment effect was evaluated on the basis of cytotoxicity, mutagenicity, and microbial load reduction. It was found that the microbial population, cytotoxicity, and mutagenicity were reduced significantly after gamma radiation treatment, and that a low dose of gamma radiation is more effective as compared to higher doses, and this treatment could possibly be used for toxicity reduction by optimizing the gamma radiation dose. Some authors have studied the toxicity of treated wastewater by AOP other than gamma radiation treatment and positive results have been reported [3, 23]. Toxicity of four types of industrial wastewater, treated by Fenton's reagent, was analyzed using bioluminescent bacteria Vibrio fischeri NRRL B-11177 [35], Daphnia magna toxicity tests [36] and toxicity of soap and detergent wastewater by Allium cepa, heamolytic, brine shrimp, and Ames test is also reported [3]. The present investigation and previous studies have pointed out that the AOPs could be used for the detoxification of industrial effluents and gamma radiation treatment found to be very efficient for cytotoxicity, mutagenicity, and microbial load reduction.

\section{Conclusion}

The textile effluents were subjected to gamma radiation treatment to the absorbed doses of 5, 10, and $15 \mathrm{kGy}$, and treatment efficiency was judged on the basis of microbial load, cytotoxicity, and mutagenicity reduction. Gamma radiation treatment revealed promising efficiency for the detoxification of toxic agents present in effluents. The higher absorbed doses did not show a significant effect as compared to low-absorbed doses, and to enhance treatment efficiency there is a need to optimize the gamma radiation dose. On the basis of results of cytotoxicity and mutagenicity, it is concluded that this treatment can be used for the detoxification of textile effluents.

\section{Acknowledgements}

The Higher Education Commission (HEC) of Pakistan is highly acknowledged for financial support under the start-up Research Project Program (Grant No. 21-194/ SRGP/R\&D/HEC/2014).

\section{References}

1. MOHAPATRA D.P., BRAR S.K., TYAGI R.D., PICARD P., SURAMPALLI R.Y. Analysis and advanced oxidation treatment of a persistent pharmaceutical compound in wastewater and wastewater sludge-carbamazepine. Sci. Total Environ. 470-471, 58, 2014.

2. BILAL N., ALI S., IQBAL M. Application of advanced oxidations processes for the treatments of textile effluents. Asian J. Chem. 26, 1882, 2014.

3. IQBAL M., BHATTI I.A. Re-utilization option of industrial wastewater treated by advanced oxidation process. Pakistan J. Agric. Sci. 51, 1141, 2014.
4. IQBAL M., BHATTI I.A. Gamma radiation $/ \mathrm{H}_{2} \mathrm{O}_{2}$ treatment of a nonylphenol ethoxylates: Degradation, cytotoxicity, and mutagenicity evaluation. J. Hazard. Mater. 299, 351, 2015.

5. IQBAL M., NISAR J. Cytotoxicity and mutagenicity evaluation of gamma radiation and hydrogen peroxide treated textile effluents using bioassays. J. Environ. Chem. Eng. 3, (3), 1912, 2015.

6. UL HAQ Z., JAMIL Y., IRUM S., RANDHAWA M.A., IQBAL M., AMIN N. Enhancement in the germination, seedling growth and yield of radish (Raphanus sativus) using seed pre-sowing magnetic field treatment. Pol. J. Environ. Stud. 21, (2), 3692012.

7. ADEEL S., USMAN M., HAIDER W., SAEED M., MUNEER M., ALI M. Dyeing of gamma irradiated cotton using Direct Yellow 12 and Direct Yellow 27: improvement in colour strength and fastness properties. Cellulose 22, (3), 2095, 2015.

8. AJMAL M., ADEEL S., AZEEM M., ZUBER M., AKHTAR N., IQBAL N. Modulation of pomegranate peel colourant characteristics for textile dyeing using high energy radiations. Ind. Crop. Prod. 58, 188, 2014.

9. BOKHARI T.H., KASHIF M., BHATTI I.A., ZUBAIR M., ADEEL S., YOUSAF M., AHMAD M., IQBAL M., USMAN M., ZUBER M. Degradation Study of CI Reactive Yellow 145 by Advanced Oxidation Process. Asian J. Chem. 25, (15), 8668, 2013.

10. IQBAL J., CECIL F., AHMAD K., IQBAL M., MUSHTAQ M., NAEEM M., BOKHARI T.H. Kinetic study of Cr (III) and $\mathrm{Cr}$ (VI) biosorption using Rosa damascena phy-tomass: a rose waste biomass. Asian J. Chem. 25, 2099, 2013.

11. MANZOOR Q., NADEEM R., IQBAL M., SAEED R., ANSARI T.M. Organic acids pretreatment effect on Rosa bourbonia phyto-biomass for removal of $\mathrm{Pb}$ (II) and $\mathrm{Cu}$ (II) from aqueous media. Bioresource Technol. 132, 446, 2013.

12. ULLAH I., NADEEM R., IQBAL M., MANZOOR Q. Biosorption of chromium onto native and immobilized sugarcane bagasse waste biomass. Ecol. Eng. 60, 99, 2013.

13. YOUNAS A., NADEEM N., IQBAL M. Ag(I), Cr(VI) and $\mathrm{Pb}$ (II) adsorption from aqueous media onto different adsorbent types. Asian J. Chem. 27, (9), 3308, 2015.

14. KHAN A.A., IQBAL N., ADEEL S., AZEEM M., BATOOL F., BHATTI I.A. Extraction of natural dye from red calico leaves: gamma ray assisted improvements in colour strength and fastness properties. Dyes Pigments 103, 50,2014

15. KHALID M., BOKHARI T.H., AHMAD M., BHATTI H.N., IQBAL M., GHAFFA.R. A., QADIR M.I. Evaluation of carrier added and no carrier added 90 Y-EDTMP as bone seeking therapeutic radiopharmaceutical. Pakistan J. Pharm. Sci. 27, (4), 813, 2014.

16. ABBAS W., BOKHARI T.H., BHATTI I.A., IQBAL M. Degradation Study of Disperse Red F3BS by Gamma Radiation $/ \mathrm{H}_{2} \mathrm{O}_{2}$. Asian J. Chem. 27, (1), 282, 2015.

17. WINID B. Environmental threats of natural water contamination with Polybrominated Diphenyl ethers (PBDEs). Pol. J. Environ. Stud. 24, 1, 47, 2015.

18. LIU J., ZHOU Z., SUN S., NING X., ZHAO S., XIE W., WANG Y., ZHENG L., HUANG R., LI B. Concentrations of heavy metals in six municipal sludges from Guangzhou and their potential ecological risk assessment for agricultural land use. Pol. J. Environ. Stud. 24, 1, 165, 2015.

19. NĘDZAREK A., BONISŁAWSKA M., TÓRZ A., GAJEK A., SOCHA M., HARASIMIUK F.B. Water quality in the central reach of the Ina River (Western Pomerania, Poland). Pol. J. Environ. Stud. 24, (1), 207, 2015. 
20. WANG D-Y, CHU W-L., KOK Y-Y. Assessment of Paracetamol (Acetaminophen) Toxicity in Microalgae. Pol. J. Environ. Stud. 24, (2), 735, 2015.

21. RIZZO L., DELLA SALA A., FIORENTINO A., PUMA G.L. Disinfection of urban wastewater by solar driven and UV lamp- $\mathrm{TiO}_{2}$ photocatalysis: Effect on a multi drug resistant Escherichia coli strain. Water Res. 53, 145, 2014.

22. DERESZEWSKA A., CYTAWA S., TOMCZAKWANDZEL R., MEDRZYCKA K. The effect of anionic surfactant concentration on activated sludge condition and phosphate release in biological treatment plant. Pol. J. Environ. Stud. 24, (1), 83, 2015.

23. RIZZO L. Bioassays as a tool for evaluating advanced oxidation processes in water and wastewater treatment. Water Res. 45, (15), 4311, 2011.

24. IQBAL M., BHATTI I.A., ZIA-UR-REHMAN M., BHATTI H.N., SHAHID M. Efficiency of advanced oxidation processes for detoxification of industrial effluents. Asian J. Chem. 26, (14), 4291, 2014.

25. LEME D.M., MARIN-MORALES M.A. Allium cepa test in environmental monitoring: a review on its application. Mutat. Res./Rev. Mutat. Res. 682, (1), 71, 2009.

26. BEKAERT C., RAST C., FERRIER V., BISPO A., JOURDAIN M., VASSEUR P. Use of in vitro (Ames and Mutatox tests) and in vivo (Amphibian Micronucleus test) assays to assess the genotoxicity of leachates from a contaminated soil. Org. Geochem. 30, (8), 953, 1999.

27. IQBAL M., BHATTI I.A., ZIA-UR-REHMAN M., BHATTI H.N., SHAHID M. Efficiency of advanced oxidation processes for detoxification of industrial effluents. Asian J. Chem. 26, (14), 4291, 2014.

28. IQBAL M., BHATTI I.A. Re-utilization option of industrial wastewater treated by advanced oxidation process. Pakistan J. Agric. Sci. 51, (4), 1141, 2014.

29. OECD. Guidelines for the Testing of Chemicals. Proposal for Updating Guideline 208. Terrestrial Plant Test: 208. Seedling Emergence and Seedling Growth Test, Draft Document. 2003

30. USEPA. Lettuce seed germination (Lactuca sativa), in: Protocol for Short Term Toxicity Screening of Hazardous Waste Sites, Environmental Research Laboratory, Corvallis, OR EPA/600/3-88/029. 1989.

31. SELÇUK H., EREMEKTAR G., MERIÇ S. The effect of pre-ozone oxidation on acute toxicity and inert soluble COD fractions of a textile finishing industry wastewater. J. Hazard. Mater. 137, (1), 254, 2006.

32. EREMEKTAR G., SELCUK H., MERIC S. Investigation of the relation between COD fractions and the toxicity in a textile finishing industry wastewater: effect of preozonation. Desalination. 211, (1), 314, 2007.

33. SOMENSI C.A., SIMIONATTO E.L., BERTOLI S.L., WISNIEWSKI J.R.A., RADETSKI C.M. Use of ozone in a pilot-scale plant for textile wastewater pre-treatment: physico-chemical efficiency, degradation by-products identification and environmental toxicity of treated wastewater. J. Hazard. Mater. 175, (1), 235, 2010.

34. SELCUK H., MERIC S. Ozone pre-oxidation of a textile industry wastewater for acute toxicity removal. Global NEST J. 8, (2), 95, 2006.

35. BARBUSISKI K. Toxicity of industrial wastewater treated by Fenton's reagent. Pol. J. Environ. Stud. 14, (1), 11, 2005.

36. SELCUK H. Decolorization and detoxification of textile wastewater by ozonation and coagulation processes. Dyes Pigments 64, (3), 217, 2005. 